\title{
AIKUISKOULUTUKSEN HAKEVAA TOIMINTAA TYÖPAIKOILLE
}

\section{Työväen Akatemian projektissa luottamusmiehet avainasemassa}

$\mathrm{N}$ oin neljännesvuosisata sitten ruotsalaiset aikuiskouluttajat lanseerasivat markkinoille käsitteen uppsökande verksamhet. Tarkoituksena oli tällöin vähentää koulutuksen eriarvoisuutta, tuoda aikuisopinnot lähemmäksi myös tavallista kansaa, vähän koulutettuja suorittavaa työtä tekeviä, jopa maahanmuuttajia. Ruotsin valtio tuli hankkeen tukimieheksi ja rahoittajaksi. Parikymmentä vuotta myöhemmin pohjimmiltaan samaan tavoitteeseen tähtäävä toiminto konkretisoitui uudelleen naapurimaassamme kymmenien miljoonien eurojen Kunskapslyftet-hankkeessa, jossa kymmenien tuhansien vähän koulutettujen ruotsalaisten yleissivistävää ja ammatillista koulutusta kohotettiin merkittävästi. Aikuiskoulutus on naapurissamme aina tähdännyt myös tasa-arvoon niin, että heikompiosaiset ryhmät on koulutuksen lainsäädännössäkin erikseen mainittu koulutuksen kohderyhminä.

Suomessa tasa-arvotavoitteen kultakausi aikuiskoulutuksen nykyhistoriassa ajoittui 70-luvulle aikuiskoulutuskomiteaan ja sitä seuraavaan keskitettyyn suunnitteluoptimismiin. Tasa-arvo periaate kirjattiin moneen kertaan, mutta konkreetit toimet jäivät vähemmälle. Massamittainen työttömyys ja Kiina-ilmiö ovat nyt Suomessa fokusoineet aikuiskoulutusta kouluttamattomiin ja vähänkoulutusta saaneisiin: on syntynyt Nosteohjelma, jonka kohteena ovat ilman ammatillista koulutusta olevat aikuiset. Tavoite on jo aiempaan tuttuun tapaa pantu paperille, ministerit puhuvat ja rahaakin on jaossa. Kyllä se siitä!

Tilastot ja arki puhuvat silti omaa kiistämätöntä kieltään. OECD kehui aikuiskoulutuksemme korkeita lukuja, mutta totesi samalla, että erot eri väestöryhmien välillä aikuiskoulutukseen osallistumisessa ovat erittäin suuret. Yksinkertaistaen: selvä enemmistö vähän koulutetuista aikuisista ei osallistu aikuiskoulutukseen. Pääosa näistä lukeutuu työväestöön, mukana on myös vanhempaa viljelijäväkeäkin. Osallistumattomien valtaosa löytyy kuitenkin vähän koulutettujen palkansaajien keskuudesta.

\section{SUURTEN TYÖPAIKKOJEN \\ LUOTTAMUSHENKILÖT \\ VERTAISOHJAAJIKSI}

1990-luvun loppupuolella Työväen Akatemia oli toteuttanut mm. aktiiviin kansalaisuuteen liittyviä Grundtvig-projekteja ruotsalaisten ja saksalaisten "sisaropistojen” ja sivistysjärjestöjen kanssa.

Näitä työelämää lähellä olevia koulutuslaitoksia kiinnosti projekti, jolla voitaisiin etsiä uusia keinoja, kuinka tavoittaa aikuiskoulutuksen ulkopuolella olevia mukaan aikuiskoulutukseen. Partnerien yhteisen ammattiyhdistystaustan vuoksi projektin perusasetelma hahmottui nopeasti. Ydintoimijaksi valitsimme ammattiyhdistysliikkeen luottamushenkilöt, suurten tai keskisuurten yritysten luottamusmiehet. Pienten yritysten haasteet todettiin niin suuriksi, ettei omien voimavarojen uskottu tässä vaiheessa niihin riittävän. Niin pohjoismainen kuin saksalainenkin luottamushenkilöjärjestelmä on etenkin teollisuusyrityksissä vakiinnuttanut asemansa työntekijöiden etujen ajajana sekä työntekijöiden muidenkin ongelmien käsittelijänä. Moderni luottamusmies on kiinteästi mukana yrityksen ja henkilöstön muutosprosessissa ja kehittämisessä. Tällä perusteella uskoimme luottamushenkilöiden kykenevän helposti ja vakuuttavasti lähestymään työtovereitaan myös aikuiskoulutukseen liittyvissä asioissa. Projekti nimesi luottamusmiehet aikuiskoulutuksen informaattoreiksi, motivaattoreiksi ja vertaisohjaajiksi. Tavoitteenamme oli kytkeä koulutus luottamusmiehen kautta läheisesti työelämän arkeen ja näin arkipäiväistää myös koulutus.

Suomessa, Ruotsissa, Ala-Saksissa ja Kataloniassa yhteistyökumppaneina toimivat ammattiliitot löytyivät helposti. Ilman ammattijärjestöjen opiskelijahankintaa, organisatorista ja merkittävää taloudellista panostusta projektin läpivieminen ei olisikaan ollut mahdollista. Bulgariassa toiminta oli, historiallisesta taakasta johtuen, hieman uutuudenjäykkää. Projektin tavoitteeksi ase- 
tettiin kouluttaa luottamusmiehistä noin 250 vertaisohjaajaa työpaikoille. Vertaisohjaajan tehtävien niveltäminen osaksi luottamusmiehen toimenkuvaa nähtiin haasteena, joka voisi laajemminkin vaikuttaa työpaikalla tapahtuvaan osapuolten väliseen yhteistoimintaan. Koulutuksen ei siis välttämättä tarvitsisikaan olla sopeuttajan osassa, kuten tavallisesti, vaan se voisi toimia muutoksen moottorina. Yhteistoiminta yrityksen johdon ja luottamusmiehen välillä oli välttämätön edellytys, jotta vertaisohjaajuuteen liittyvät tehtävät etenisivät. Todettakoon, että suomalaisten luottamusmiesten mandaatti toimia koulutuksen alueella yrityksissä jää jälkeen niistä valtaoikeuksista, mitä ruotsalaisilla ja saksalaisilla työelämän luottamushenkilöillä on käytettävissään.

\section{VERTAISOHJAAJA OPISKELIJAN MOTIVAATTORINA}

Vertaisohjaajan tehtävissä keskeisin taito on motivoida työtovereita osallistumaan koulutukseen. Potentiaalisten opiskelijoiden itsetunnon kohottaminen ja koulutuksen merkityksellisyyden välittäminen opiskelijoille tulivat vertaisohjaajan haastavimmaksi tehtäväksi. Opiskelijakontaktin kanssa yhtä tärkeäksi asiaksi muodostui yhteistoiminnan aikaansaaminen työnantajan ja yrityksen kanssa koulutuksen suunnittelussa ja koulutukseen ohjaamisessa sekä näitä tukevien järjestelyjen aikaansaamisessa. Luottamusmiehen luontaiset mahdollisuudet ottaa elävä kontakti sekä työtoveriinsa että työnantajan koulutuskysymyksissä näyttivät toimivan koko projektin ajan erittäin luontevasti. Aikuiskoulutuksen informaatiojärjestelmä toimii tänään Suomessa ja osin myös partnerimaissa elektronisesti ja on käytännössäkin lähes jokaisen saavutettavissa. Tämän järjestelmän hyväksikäyttäminen ja hallinta otettiin myös osaksi vertaisohjaajan koulutusta. Kattavan ja kehittyneen tietoverkon merkitys tähän asti aikuiskoulutukseen osallistumattomien aktivoinnissa ei kuitenkaan yksin riitä. Se on kuin auto ilman ohjaajaa ja polttoainetta. Tähän samaan kategoriaan luokittelimme vertaisohjaajien työkentässä myös työelämän ja aikuiskoulutuksen säädöspohjan tuntemisen sekä opintososiaalisen tukijärjestelmän; välttämättömiä, mutta sittenkin vain apuvälineitä. Koulutuksen keskiöön sijoittui kontaktin ottaminen koulutettaviin ja heidän motivoimisensa sekä yhteistoiminnasta sopiminen työnantajan kanssa.
KOLMEN OPINTOVIIKON KOKONAISUUS MODUULEINA

Kaksivuotisessa projektissa kunkin vertaisohjaajaryhmän koulutus toteutettiin kolmen opintoviikon mittaisena siten että neljän kahden päivän mittaisen moduulin väleihin rakennettiin yksilölliset analyysit, harjoitukset ja suunnittelutehtävät työpaikoilla. Kokemuksia pyrittiin vaihtamaan lähettämäl-

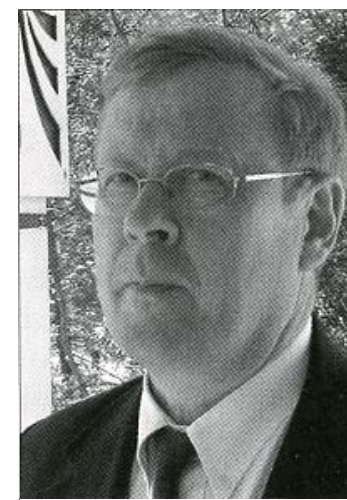

Kari Kinnunen lä tarkkailijoita vierailemaan ulkomaisten partnerien toteuttamiin moduuleihin. Projektin jälkiarviointi on vielä suorittamatta, mutta sormituntuma viittaisi siihen, että vertaisohjaajakoulutuksen kestona projektin kolme opintoviikkoa saattaisivat hyvinkin riittää, mikäli koulututusta vielä myöhemmin päivitettäisiin lisäkoulutuksella. Koulutuksen sisällötkin kaipaavat edelleen kehittämistä. Valmistaudumme parhaillaan hankkeen jatkamiseen ja levittämiseen sekä kansallisella että kansainvälisellä tasolla.

LLLA- animateurs- projektin idea ja haaste on yleiseurooppalainen ja ajankohtainen. Partnerit näkivät siinä sekä yhteiskunnallisen ulottuvuuden, joka konkretisoituu koulutuksen merkityksessä eurooppalaisen talouden tukijalkana mutta samanaikaisesti myös tasa-arvon edistäjänä. Toisaalta työmarkkinatasolla LLLA-animateurs avaa onnistuessaan mahdollisuuden uudistavaan ja kehittävään työmarkkinakäytäntöön, jossa on tilaa myös inhimilliselle kasvulle.

Aikuiskoulutuksen vertaisohjaajien tehtävä työpaikoilla voidaan lyhyesti tiivistää kolmeen ydinkohtaan. Näistä ensimmäinen on vähänkoulutettujen ammattitaidon ylläpitäminen aikuiskoulutuksen avulla. Toiseksi työelämän aikuiskoulutus on aina osapuolten välistä yhteistoiminta, jossa vertaisohjaajan välittävä tehtävä korostuu. Kolmanneksi modernien tietoverkkojen käyttö aikuiskoulutukseen hakeuduttaessa vaatii tuekseen aina myös henkilökohtaista ohjausta uskottavan tukihenkilön taholta.

\section{Kari Kinnunen}

"Lifelong learning animateurs", Grundtvig 1 projekti 2002-2004 